\title{
Integration of Al-Quran Education and Minangkabau Culture on Subjects in Formal Schooling
}

\author{
Junaidi $^{1}$, Nora Susilawati ${ }^{1}$, Reno Fernandes ${ }^{1, *}$, Ike Sylvia ${ }^{1}$, Eka Vidya Putra ${ }^{1}$ \\ ${ }^{I}$ Department of Sociological Education, Faculty of Social Science, Universitas Negeri Padang, Padang, Indonesia \\ *Corresponding author.Email: renofernandes@fis.unp.ac.id
}

\begin{abstract}
This research is based on emerging Al-Quran and Minangkabau culture lesson as a character education in West Sumatra. This character education at the formal school was accommodated by local content subjects at the 1994 curriculum. In subsequent developments as the national curriculum changes, the character education policy changed into the integration of Al-Qur'an and Minangkabau culture lesson in all subjects in the Formal school. This research uses qualitative methods to see how the implementation of integration of Al-Quran and Minangkabau culture lesson in the subjects at high school in West Sumatra. The results showed that the education program issued by the Education Department of West Sumatra Province is an innovation of character education based on socio-cultural. Although in its execution has not going according to expectation, the obstacle in applying innovation lies in the teacher's competence in planning, implementing and evaluating learning. The condition is caused by communication channels between stakeholders in education institutions in West Sumatra have not gone well..
\end{abstract}

Keywords: integrated, character education, formal school

\section{INTRODUCTION}

Globalization is characterized by the sophistication of technology; Communication and information lead Indonesia into the global network system. The rush of technology, communication and information brings the community to get a wide range of information and knowledge from anywhere and anytime [1]. This situation does not close the possibility of bring negative impact to the young generation of Indonesia. Globalization also brings lifestyle changes that sometimes diverged from cultural values [2].

Educational institution in Indonesia have program to anticipate the diversity of the negative impacts of globalization, namely by applying the character of Education [3] Education of characters is the process of embedding good habits through educational institutions to form Learners a very able to behave and act based on the values high in society [4]. Thomas Lickona through his work The Return of Character Education explains the importance of character education implemented in Schools [5]. Character education as defined by Ryan and Bohlin, contains three important elements, namely knowing goodness, loving kindness, and doing good [6].

According to [7] character education is a conscious effort that is planned and directed through the learning environment for the growth and development of all human potential who have personality and moral character. Value education is the basis of character education. Thus, efforts to instill and develop the cultural values of a society, it is very important to carry out socio-culture based character education [8].

Socio-cultural based character education in West Sumatra has been carried out since the 1994/1995, through local content subjects [9]. The regulation governing its implementation is the Governor's Decree No. 011.08.C.1994 regarding the local content curriculum for elementary schools and junior high schools. This education policy in West Sumatra was perfected through regional regulation No. 2 of 2009 concerning the basis of educational development. In this regulation it is stressed that the delivery of education must refer to the Minangkabau adat philosophy, namely: "Adat Basandi Syara, Syara Basandi Kitabullah".

Substitution of the national education curriculum into the 2013 Curriculum, also changes composition and structure of the subjects. One of the subjects which miss is Local Content. Thus, subjects that contain elements of character education such as the education of the Qur'an, Arabic Literacy and the Natural Culture of Minangkabau are no longer subjects in the School. This condition leads to the birth of West Sumatra Governor Regulation No. 73 of 2012 concerning Guidelines for implementing character education in schools. The regulation provides the basis for the implementation of character education based on sociocultural that adapts to the 2013 national education curriculum.

Since 2012, Government West Sumatra through the education office has developed a model of the integration of the Qur'an and Minangkabau culture in subjects in formal schools. This model is implemented as an innovation in carrying out character education based on 
socio-cultural. The application of the integration of AlQur'an education and Minangkabau culture can only be carried out in the $2017 / 2018$. As a new education program is implemented, it is necessary to conduct an ongoing evaluation. In principle, evaluation is needed so that improvements occur to achieve the expected goals.

Research on the implementation of character education has been conducted many of them [10], researching the implementation of character education in the activities of intrurricular, extra-curricular, and Hidden curriculum in elementary school in Yogyakarta. Further research was conducted by [1] about the potential of local wisdom in the formation of identity and national character and research conducted by about development of character education based on socio-cultural values model in high School students in Minahasa. Those studies only describe the importance of the implementation and development of character education implemented based on social culture. In contrast to previous research, this article uses a sociological approach to look at the implementation of AlQur'an Education and Minangkabau culture that is integrated with subjects in formal schools. This article will comprehensively describe the form and basis of the implementation of the Qur'an and Minangkabau Cultural Education in secondary schools in West Sumatra. In addition, research analysis limits the implementation of Al-Qur'an education and Minangkabau culture by using the diffusion theory of Everett M. Rogers.

\section{RESEARCH METHODOLOGY}

This article describes the results of research using a qualitative approach with descriptive methods. Data collected by purposive sampling technique. Data collection is done through observation of participation, interviews and study of documents obtained through government regulations, ministerial regulations, regional regulations, curriculum implementation guidelines, articles in magazines, news in print and electronic media. The data is processed using an interactive analysis approach from Miles and Huberman, which must go through the stages of data collection, data reduction, data processing and data verification [11].

\section{RESEARCH RESULTS AND DISCUSSION}

\subsection{Research Results}

\subsubsection{Social Culture Based Character Education}

The character education based on Socio-cultural in West Sumatra has been carried out in a structured manner since the school year of 1994/1995. The Regulations that arrange the implementation is Governor Decree No. 011.08.C.1994 about the local content curriculum for elementary and junior high schools. That decision mentioned five subjects that must be taught in schools, (1) Minangkabau Culture (BAM), (2) Read the writing of the Qur'an, (3) Read the writing of Arabic Malay letters, (4) Minangkabau traditional skills (KTM) ), and (5) Agricultural skills are taught as local content [9].

Character education based on socio-cultural education is strengthened through West Sumatra province regulation number 2 of 2009 that concerning the implementation of education. In this case, it is stated that the implementation of education in West Sumatra is based on the philosophy of life that held fast by the Minangkabau community namely "Adat Basandi Syara', Syara' Basandi Kitabullah." This regulation emphasizes that basic value of Al-Qur'an and Minangkabau culture learning must include in organization of education in West Sumatera by considering national curriculum that arrange by central government

The changing of the Education Unit Level Curriculum (KTSP) to the 2013 Curriculum has the effect of losing the Local Content subjects that have been set by the West Sumatra Provincial Government as subjects in Formal Schools. Responding to that change in national education policy, the Governor of West Sumatra issued Regulation No. 73 of 2012 concerning the instructions for implementing character education in schools. The execution of character education in West Sumatra is made from references to the Research and Development Center of the Ministry of National Education Curriculum. Character education values developed by schools are; Islamic religious character values; the nation's culture; and local culture

The Curriculum Research and Development Center of the Ministry of National Education develops 18 national character values that must be incorporated into the implementation of character education in formal schools. The implementation of character education is contextual based on socio-cultural values in the community. The Provincial Government of West Sumatra translates these values in accordance with the values that form the basis of Minangkabau people's behavior. The values of these values can be seen in the table below: 
Table 1 The Value of National Character with Religious Values and Local Culture of Minangkabau

\begin{tabular}{|c|c|c|c|}
\hline \multirow[t]{2}{*}{ No } & \multicolumn{3}{|l|}{ Character Value } \\
\hline & $\begin{array}{l}\text { The nation's } \\
\text { culture }\end{array}$ & Religious Values & Local Wisdom \\
\hline 1 & Religious & $\begin{array}{l}\text { Iman, Islam, Ihsan, } \\
\text { Takwa }\end{array}$ & $\begin{array}{l}\text { Adat Basandi Syara', Syara' Basandi Kitabullah, } \\
\text { Syara' Mangato Adat Mamakai }\end{array}$ \\
\hline 2 & Honest & Shiddiq & Nan bana ditagakan \\
\hline 3 & Tolerance & Tasamudh & $\begin{array}{l}\text { Lamak diawak katuju diurang, awak mandapek urang } \\
\text { indak maraso kahilangan, baso elok budi katuju }\end{array}$ \\
\hline 4 & Discipline & Taat dan Istiqamah & Alua jo patuik, patuik jo mungkin \\
\hline 5 & Hard Work & Mujahadah & $\begin{array}{l}\text { Nak kayo kuek mancari, nak pandai kuek baraja, nak } \\
\text { mulia tapek-i janji, nak labo namuah barugi }\end{array}$ \\
\hline 6 & Creative & Tajdid & $\begin{array}{l}\text { Indak rotan aka pun jadi ; Kok duduak marawuik } \\
\text { ranjau, kok tagak maninjau jarak, sambia badiang nasi } \\
\text { masak sambia manyalam minum aie. }\end{array}$ \\
\hline 7 & Independent & Nasiyah & Indak maangok kalua badan \\
\hline 8 & Democratic & & $\begin{array}{l}\text { Duduak basamo balapang-lapang, duduak sorang } \\
\text { basampik-sampik ;Saciok bakayam sadanciang bak } \\
\text { basi. }\end{array}$ \\
\hline 9 & Curious & Himmah & Alam takambang jadi guru \\
\hline 10 & Nationalism & Syu'ubiyah & $\begin{array}{l}\text { Suku ndak dapek diasak, gala ndak dapek dialiah, } \\
\text { kampuang ndak dapek dituka. }\end{array}$ \\
\hline 11 & $\begin{array}{l}\text { Love the } \\
\text { Motherland }\end{array}$ & $\begin{array}{l}\text { Baldatun } \\
\text { thayyibatun } \\
\text { warabbun ghafur }\end{array}$ & $\begin{array}{l}\text {-Tagak kampuang mamaga kampuang, tagak nagari } \\
\text { mamaga nagari }\end{array}$ \\
\hline 12 & $\begin{array}{l}\text { Appreciate } \\
\text { achievements }\end{array}$ & Fastabiqu/Khairat & $\begin{array}{l}\text { Kok manang jan manapuak dado, kok kalah jan } \\
\text { manyasa. }\end{array}$ \\
\hline 13 & $\begin{array}{l}\text { Friendly/Commu } \\
\text { nicative }\end{array}$ & Ukhuwwah & $\begin{array}{l}\text { Nan tua dihormati, nan ketek disayangi, samo } \\
\text { Gadang dibawo baiyo }\end{array}$ \\
\hline 14 & Peaceful & Mahabbah & $\begin{array}{l}\text { Kaluak paku kacang balimbing tampurung lenggang- } \\
\text { lenggangkan dibaona kurang ka Saruaso, anak } \\
\text { dipangku kamanakan dibimbiang urang kampuang } \\
\text { dipatenggangkan, }\end{array}$ \\
\hline 15 & Like to read & Tadarrus, Tadabbur & $\begin{array}{l}\text { Alam takambang jadi guru, bumi } \\
\text { Tabantang tampek diam }\end{array}$ \\
\hline 16 & $\begin{array}{l}\text { Environmental } \\
\text { care }\end{array}$ & Ishlah & $\begin{array}{l}\text { Jago nagari jan binaso, jago } \\
\text { Kampuang jan tinggakan. }\end{array}$ \\
\hline
\end{tabular}




\begin{tabular}{|l|l|l|l|}
\hline 17 & Social Care & Taawun & $\begin{array}{l}\text { Kaba baiak baimbauan, kaba buruak } \\
\text { Bahambauan }\end{array}$ \\
\hline 18 & Responsibility & Amanah & $\begin{array}{l}\text { Tangan mancancang bahu mamikue; Barani karano } \\
\text { bana takuik karano salah; }\end{array}$ \\
\hline
\end{tabular}

Source: elaborated from character education values in Sumatera Barat [12]

worksheets; b). Apply character values in the learning process through the learning steps, which include:

\subsubsection{The integration of the Al-Quran within Minangkabau culture}

Character education approach in schools is done by giving role models to students. The strategy of implementing character education in schools carried out by: integrating character values in the education process, developing the school culture; Personal development activities (counseling guidance, small group guidance and extracurricular activities). This research specifically discusses the integration of Al-Qur'an and Minangkabau values in the learning process.

Integration of the Qur'an and Minangkabau culture can be done on subjects taught in schools such as: Islamic Religious Education, Indonesian Language, English, Mathematics, Chemistry, Physics, Biology, History, Economics, Geography, PPkn, PKWU / PKK, Penjaskes, Sociology, Art and Culture (West Sumatra Province Education Office, 2017). Application of Integration is carried out by; a) Integration of character values relevant to learning material in the Syllabus, Learning Implementation Plan (RPP), Teaching Materials, student Introduction; Core activities (exploration, elaboration and confirmation), and Closing. c). Integrate the verses of the Koran in every material in learning.

In carrying out the integration of the Qur'an and Minangkabau culture with these subjects is largely determined by teacher competence. Furthermore, the competencies that must be possessed by teachers in implementing character education are: Teachers must be able to understand well the basic competencies to be taught; Teacher must have knowledge relating to Minangkabau cultural values and the ability to explore and interpret the contents of the Qur'an related to the basic competencies of the subjects; Teachers must be able to teach contextually that is to link teaching materials with the values of the Qur'an and Minangkabau culture.

For example, in the subject of Sociology with subject matter deviant behavior. The first step teacher must search for verses in the Qur'an relating to deviant behavior. This value transformation gives on learning activities (introduction, core, and conclusion). Further explanation can be seen from the detailed learning activity table below:

Table 2 Sociological learning activities with material notion of deviant behavior

\begin{tabular}{|c|l|}
\hline \multicolumn{1}{|c|}{ Activities } & \multicolumn{1}{c|}{ Description of activities } \\
\hline Introduction & $\begin{array}{l}\text { Teacher creates a pleasant learning atmosphere by saying greetings. } \\
\text { One Student Leads Prayer to create a religious atmosphere in learning } \\
\text { Teacher pays attention to student attendance } \\
\text { Teacher Motivates students } \\
\text { Teacher asks one of the students to read QS-Hujarat verse } 10 \text { about the prohibition of } \\
\text { adultery. } \\
\text { Teacher explains about the Minangkabau traditional proverb related to teaching } \\
\text { material "Rarak kalikih dek binalu Tumbuah sarumpun di tapi tabek". Its meaning: } \\
\text { shameless, can be ostracized in social life. } \\
\text { Teacher conveys competencies to be achieved and the benefits of the material being } \\
\text { taught } \\
\text { In learning activities, Teacher utilizes the discovery learning model } \\
\text { Teacher conveys the scope and assessment techniques that will be used. }\end{array}$ \\
\hline Core activities \\
$\begin{array}{l}\text { Learners observe videos about teaching material that deviates behavior } \\
\text { Teacher provides the opportunity for students to identify as many problems as }\end{array}$ \\
\hline
\end{tabular}




\begin{tabular}{|c|c|}
\hline & $\begin{array}{l}\text { possible that related to the video that has been observed and related to the material for } \\
\text { understanding distorted behavior. } \\
\text { Learners gather relevant information to answer the questions that have been identified } \\
\text { through various sources relating to, ideas of deviant behavior. } \\
\text { Learners analyze information from reading various source books to answer questions } \\
\text { that have been assigned } \\
\text { Discuss the results of data processing and verification of the results of processing with } \\
\text { data at the source related to the material presented } \\
\text { Learners conclude the results of the discussion and each group is presented alternately }\end{array}$ \\
\hline $\begin{array}{l}\text { Closing } \\
\text { learning }\end{array}$ & $\begin{array}{l}\text { Teacher with students make a summary / conclusion about the materials that has been } \\
\text { discussed } \\
\text { Teacher reflects the activities that have been carried out both about the process and the } \\
\text { results achieved } \\
\text { The teacher makes an assessment of the material discussed in learning activities } \\
\text { Teacher plans a follow-up activity in the form of a group assignment } \\
\text { Teacher closes the lesson by thanking and saying greetings }\end{array}$ \\
\hline
\end{tabular}

Source: Source: Data derived from Guidelines for integration of the Qur'an and Minangkabau Culture in sociology subjects [13].

\subsubsection{The implementation of the Quran integration and Minangkabau culture in the teaching.}

Based on the data obtained in the study, the implementation of the integration of the Qur'an and Minangkabau Culture with subjects did not seem to work as it should be. Yet, teacher as implementers have not been able to make learning plans in accordance with integration guidelines. It shall be seen from the teacher's implementation of learning plans (RPP) similar to the examples of learning implementation plans issued by the Department of Education. This means that the teacher only does 'copy paste' without developing learning activities in making lesson plans.

Observations carried out when the teacher teaches in class. Teacher does not carry out learning in accordance with the learning implementation plan that they have made. Teacher still uses the lecture method. This resulted the orientation of learning in school does not provide a balanced portion in developing knowledge, attitudes and skills.

That phenomenon occurs because teacher does not understand the purpose and benefits of integrating the Qur'an and Minangkabau culture properly. The cause can be explained by the theory of innovation diffusion by Everett M. Rogers. According to Everett M. Rogers the diffusion of innovation consists of elements of innovation, communication channels, time frames, and social systems
[14]. Therefore it will be obtained why the character education program integration of Al-Qur'an education and Minangkabau culture has not achieved its objectives The integration of Al-Qur'an and Minangkabau culture lesson is an innovation to the application of character education based socio-cultural. The purpose of integrating conceptually can be said to provide renewal implementation. According to Everett M. Rogers, communication channels are crucial in the diffusion of innovation. Basically, education policy making must be participatory, because participatory development policy will support the success of the policy.

In planning the Al-Qur'an Integration Program and Minangkabau culture in West Sumatra, teachers in West Sumatra felt that they were not involved in the planning of the program. The involvement of the teacher in planning the values to be integrated in the subject do not comes from the teacher but it is only made by the West Sumatra Education Office. Furthermore, it relates to communication channels and time periods, in conducting program socialization, the province of West Sumatra did not have sufficient funds to touch all teachers. This situation brings the quantity and quality of training provided to teachers is not optimal.

To support the successful implementation of new innovations, the social system of society is crucial. The social system referred to in this study is related to the habits and behavior of teachers. It was revealed from the results of this study, teacher still uses conventional methods. Ideally, learning in schools uses a curriculum with a student-oriented approach, but most teachers still 
[5] E. Rohendi, "Pendidikan Karakter Di Sekolah," EduHumaniora | J. Pendidik. Dasar Kampus Cibiru, 2016. Qur'an and Minangkabau Culture Integration Program unable to achieve the desired goals, namely students who have local character but are able to think globally as the West Sumatra provincial government aspires.

\section{CONCLUSION}

Educational institutions in Indonesia have programs to anticipate various behavioral deviations played by the younger generation, namely by implementing character education. In developing character education based on culture-based, we need to understand about the diversity of ethnic groups in Indonesia. What is meant of Indonesian national culture in this context of course a culture possessed by ethnic groups in Indonesia. Therefore, the application of character education is important considering the local values of each ethnic group.

The implementation of character education in West Sumatra has been going on for a long time, 1994 curriculum that accommodates subjects like: Read the Qur'an, read Arabic Malay writing, Minangkabau Culture, Traditional Minangkabau Skills (KTM), and agricultural skills taught as local content. Furthermore, with the 2013 curriculum change, Government of West Sumatra Province has consistently implemented an education system based on the Qur'an and Minangkabau Culture with an integrated format in all subjects in formal schools. The concept of integration of Al-Qur'an and Minangkabau Culture learning in subjects is believed to fortify students from the negative effects of Globalization. But the implementation has not been yet running as it should. It seems that the teacher has not been able to make learning plans and carry out learning with the concept of integration. This condition is caused by communication channels between policy makers from the West Sumatra education office and teachers who are not going well. This situation is exacerbated by the habits and behavior of the teacher who still maintains the old way of teaching using the lecture method.

\section{REFERENCES}

[1] M. Alfian, "Potensi kearifan Lokal dalam Pembentukan Jati Diri dan Karakter Bangsa," in The 5th

International Conference on Indonesian Studies:

"Ethnicity and Globalization," 2013, pp. 424-435.

[2] U. Fajarini, "Peranan Kearifan Lokal dalam Pendidikan Karakter," Sosio Didakt., vol. 1, no. 2, 2014.

[3] R. Fernandes, E. V. Putra, and R. Muspita, "Optimalisasi Institusi Pendidikan sebagai Pengendalian Hoax," ABDI J. Pengabdi. dan Pemberdaya. Masyarakat., vol. 1, pp. 16-20, 2019.

[4] R. Fernandes, "Adaptasi Sekolah Terhadap Kebijakan Pendidikan Inklusif," SOCIUS, vol. 4, no. 2, 2018.
[6] F. J. Nasrullah, "Pendidikan Karakter pada Anak 2015.

[7] Kaimuddin, "Implementasi Pendidikann Karakter dalam Kurikulum 2013," Din. Ilmu Vol., vol. 14, no. 1, pp. 47-64, 2014.

[8] A. L. Lonto, "Pengembangan Model Pendidikan Karakter Berbasis Nilai Sosio-Kultural pada Siswa SMA di Minahasa," MIMBAR, J. Sos. dan Pembang., vol. 31, no. $2,2015$.

[9] Agustina, "Pembelajaran Budaya Alam Minangkabau ( BAM ) sebagai Wadah Pelestarian Kearifan Lokal : antara Harapan dan Kenyataan," J. Bhs. DAN SENI, vol. 13, no. 1, 2012.

[10] P. Lestari and Sukanti, "Membangun Karakter Siswa Melalui Kegiatan Intrakurikuler Ekstra Kurikuler, dan Hidden Curriculum di SD Budi Mulia Dua Pandeansari Yogyakarta," J. Penelit., vol. 10, no. 1, pp. 71-96, 2016.

[11] Sugiyono, "Metode Penelitian Pendidikan Pendekatan Kuantitaif, Kualitatif, dan R\&D," Metode Penelitian Pendidikan Pendekatan Kuantitaif, Kualitatif, dan R\&D. 2013.

[12] Pergub Nomor 73 Tahun 2012. .

[13] Dinas Pendidikan Provinsi Sumatera Barat, Pengintegrasian Pendidikan Al Qur'an dan Budaya Alam Minangkabau pada Mata Pelajaran Sosiologi Sekolah Menengah Atas (SMA). 2017.

[14] A. S. Everett M. Rogers, "Diffusion of Innovations . Everett M. Rogers.," Am. Anthropol., 2004. dan Remaja," Semin. Psikol. dan Kemanus., pp. 978-979, 